\title{
A PRELIMINARY STUDY OF THE RELATIONSHIPS BETWEEN THE BLOOD MINERAL COMPOSITION OF DAIRY COWS AND THE MILK AND MILK FAT YIELD SIMULTANEOUSLY OBTAINED.
}

\author{
P. SAARINEN
}

Helsinki University, Department of Animal Husbandry, Viikin Experiment station, Malmi.

Received 2th october 1952.

In a previous communication (2) the effects of feeding large amounts of calcium and phosphorus supplements on the level of these minerals in the blood of dairy cows were discussed on the basis of 274 blood samples collected from 15 herds. In addition to calcium and phosphorus, however, sodium, potassium and chlorine were determined simultaneously. The milk yields and fat tests were recorded both for 24-hr. periods and also for the 3 -hr. periods corresponding to the time of taking blood samples. The possible physiological effects of variations in the blood mineral composition on the milk and milk fat yield were investigated on the basis of these data. Some of the preliminary results will be reported here.

\section{Experimental procedure.}

The initial data used for this study were the same as in the previous report (2). In studies concerning the effects of feeding and/or lactation on the blood calcium and phosphorus the 24-hr. milk yields were used as a measure of production. When investigating, however, the relationships between the blood mineral composition and the corresponding milk secretion, the 24-hr. interval seemed to be less suitable owing to the variations in blood composition and milk secretion. A distinct periodic (4 to 8-hr.) variation in milk and especially in milk fat yields, if not using oxytocine, was noticed previously (1, pp. $24-28$ and $121-122$ ). For checking similarly the variations in blood composition, samples were taken from the coccygeal artery at 4-hr. intervals for 24 hours consecutively from 3 cows. The blood samples were analyzed for calcium, sodium, potassium, inorganic phosphorus and chlorine. In each of these 3 series, differences in the values exceeding 20 per cent of the average were noticed for these minerals with the exception of chlorine. Later when 4 more cows were bled in the daytime only, 3 times at 4-hr. intervals for three consecutive 
days, the variations were also distinct, though somewhat smaller. On the basis of these data it was concluded that a milk sample, which is to correspond to a blood sample, must be secreted during a relatively short period of time.

In the earlier experiments it had also been noticed (1, p. 33) that the cows usually "let down» normally once when milked after 3 -hr. intervals, but not repeatedly at shorter intervals than about 4-hrs. When the cows in this experiment were bled only once, the 3 -hr. milking interval was used for checking the milk yield at the time of taking the blood sample. Later it was noticed, however, that on milking after a 3 -hr. period sometimes the first "letting down" was also obviously abnormal. Because of this the samples were rejected as unsatisfactory if the 3-hr. milk yield corresponded to less than 70 per or more than 130 per cent of the daily average. Hence only 217 blood and milk samples of the original 274 sampes could be used for this study.

At the time of conducting this study no oxytocine was available. It was assumed, however, that the actual effect on milk secretion might be produced by hormonal control. The application of hormone preparations like oxytocine alters the normal emptying of the udder and probably also the rhythmical function of endocrine glands related to the secretion of milk.

The analytical data for the blood minerals determined were classified according to the in magnitude so that each class included approximately the same number of observations. The milk samples were divided accordingly, and the averages with their standard errors were calculated for milk yields and fat percentages.

\section{Results.}

The results obtained are presənted graphically in figure 1 . The ordinates of these graphs present the averages of milk yields (kgs. $/ 3 \mathrm{hrs}$.) and fat percentages \pm their standard errors in groups representing different levels of minerals in the blood. The amounts of blood minerals are expressed on the axes of abscissas in terms of milligram equivalents per liter of blood. In these calculations phosphoric acid has been considered as a two equivalent acid only.

Owing to the low number of observations very few differences were found that were statistically significant.

According to the previous investigation the milk yield appeared to have a slight positive effect on the blood calcium and a slight negative effect on the blood phosphorus. This seems also to hold true when calculated on a 3-hr. basis. In addition to this it will be observed that anions in general seem to have a negative effect and cations, with the exception of potassium, a positive effect on the milk and milk fat yields. When the effects of different ratios were investigated separately, the effect of the $\mathrm{Ca} / \mathrm{P}$ ratio (calculated on the equivalent basis) appeared to be at least as positive as that of the calcium ion. The $\mathrm{Na} / \mathrm{K}$ ratio seemed to have a continuous positive effect on the milk yields. The fat percentages, however, were highest at the normal $\mathrm{Na} / \mathrm{K}$ ratio. 

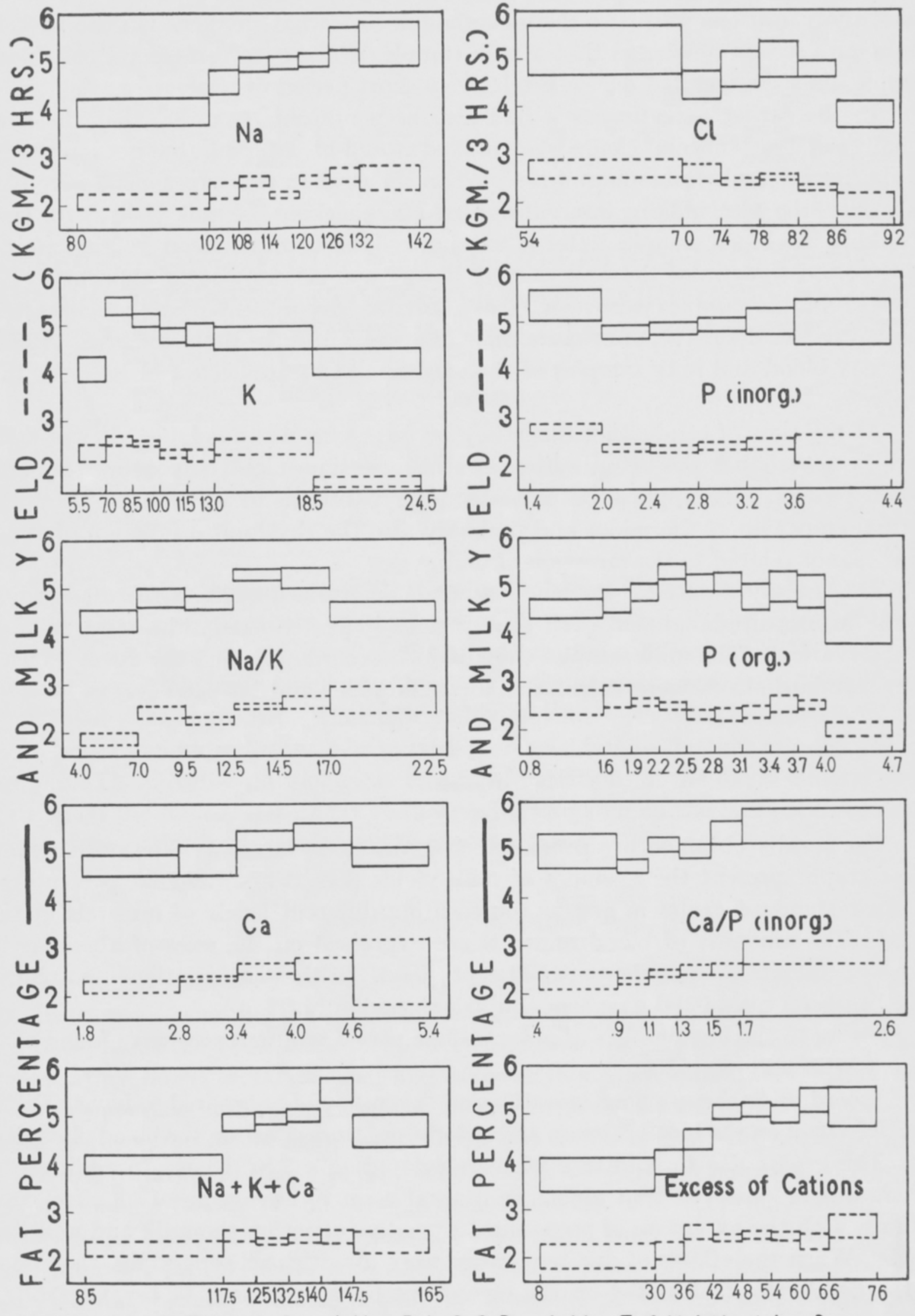

MINERALS IN BLOOD ( M. EQUIV./L. )

Figure 1. Relation between the blood mineral composition and the simultaneous milk yield and fat percentage. 
The blood sodium and/or the excess of cations in the blood showed statistically the most distinct positive effects, especially on the milk fat yields.

\section{Discussion.}

Several explanations can be found for the correlations possibly existing between the blood mineral composition and milk and milk fat yield. Three of these have considered further.

First the question arose of whether the correlations indicate variations in the rate of withdrawal of milk and emptying of the udder or variations in the actual secretion of milk. When, however, the results were calculated on the basis of 24-hr. periods, instead of 3 -hr. milking intervals, the results showed the same tendency, though somewhat less distinetly. Hence it was concluded that the relationships noticed in this study might be in some way connected also with the true secretion of milk. The fluctuations in the amount of blood minerals however may either have direct effects on milk secretion, e.g. by changing the electric charges of colloids, or they may be secondary, e.g. subordinate to variations in the hormonal control.

The potassium ion seems to differ from the general trend of cations, appearing to have a negative influence on production. Simultaneously the $\mathrm{Na} / \mathrm{K}$ ratio seems to have a positive effect. For an additional check potassium chloride was fed to three cows on individual feeding, two showing a normal blood $\mathrm{Na} / \mathrm{K}$ ratio $(9.15-14.77)$ but one a low $\mathrm{Na} / \mathrm{K}$ ratio $(5.3-7.4)$ combined with high potassium values (13.8$21.1 \mathrm{~m}$. equiv. (L of blood). When $40 \mathrm{gms}$. of sodium chloride in the feed was replaced by 52 gms. of potassium chloride per cow per day, the two normal cows produced, during a short 5-day test period, milk and fat slightly above the average for control periods. Only the cow with the low $\mathrm{Na} / \mathrm{K}$ ratio reacted negatively. It seems possible that, apart from the general effects of cations and/or excess of cations, blood potassium and the $\mathrm{Na} / \mathrm{K}$ ratio in the blood chiefly indicate variations in the hormonal control, perhaps mainly inthe rate of function of the adrenal glands and kidneys.

A similar experiment was also made concerning the effects of calcium supplements. Two cows producing $18-12$ and $16-11 \mathrm{kgs}$. of milk per day were fed individually and kept for 12 weeks on a diet which consisted of $6 \mathrm{~kg}$. timothy hay, 3-4 $\mathrm{kg}$. oat straw, $12 \mathrm{~kg}$. fodder beets, and concentrate mixture 7.2 and $6.0 \mathrm{~kg}$. respectively. After a 4 -week standard period sodium chloride in the feed was replaced first by $100 \mathrm{gm} . \mathrm{CaSO}_{4}$ for 2 weeks and then by $340 \mathrm{gm}$. of ground chalk for 3 weeks, after which the initial standard feed was resumed. In comparison with the production of standard periods the $\mathrm{CaSO}_{4}$ feeding did not show any distinct effects. The similarly calculated results of the $\mathrm{CaCO}_{3}$ feeding period are presented in table 1 .

Table 1. Effects of calcium carbonate feeding on the blood minevals and milk yield.

Average change in

Milk yield $\mathrm{kg} . /$ day $\ldots \ldots \ldots \ldots \ldots$

Milk fat yield $\mathrm{g} . /$ day $\quad \ldots \ldots \ldots \ldots \ldots$

Blood calcium mg./1. ...........

Blood inorganic phsophorus mg./1. . .

Excess of cations in blood mg. equiv./1.
Cow Lucia

$+0.5$

$+20.0$

$+28.2$

$+10.6$

$-19.9$
Cow Elo

$+0.3$

$+43.7$

$+22.2$

$-1.5$

$-10.1$
Average

$+0.4$

$+31.9$

$+25.2$

$+4.6$

$-15.0$ 
It will be noticed from table 1 . that the calcium carbonate feeding showed a positive effect on blood calcium and milk and milk fat yields, as expected on the basis of the data presented previously. The excess of cations in the blood, which was fairly high during the standard periods (average $52.6 \mathrm{~m}$. equiv./1), decreased, however, somewhat unexpectedly. This might be due to the simultaneous decrease in the amount of sodium chloride in the feed. An additional check, however, is necessary, and the possibility still exists that the variations in blood minerals, other than potassium, are also purely secondary.

\section{Summary and conclusions.}

A preliminary study of the relationships between the blood mineral composition and the simultaneous milk and milk fat yield was made on the basis of 217 blood and milk samples. The effects of blood sodium, potassium, calcium, chlorine, phosphorus, $\mathrm{Na} / \mathrm{K}$ and $\mathrm{Ca} / \mathrm{P}$ ratios and the excess of cations in the blood were investigated separately.

The inorganic cations, except potassium, appeared to show in general a positive influence and the inorganic anions a negative influence on the milk and milk fat yields.

Some of the relationships noticed in this study might indicate actual effects of blood minerals on milk secretion. Some others, however, might be secondary, and possibly related to variations in hormonal control. The fluctuations in blood potassium and blood $\mathrm{Na} / \mathrm{K}$ ratio, for example, might primarily indicate the efficiency of adrenal and renal function.

\section{Acknoroledgements.}

The author wished to extend his sincere thanks to I. Poijärvi, Head of the Department of Animal Husbandry, for making the necessary arrangements to conduct this study at the Agricultural Research Centre.

\section{REFERENCES.}

(1) Safrinen, Pellervo, 1944. Lehmän veriplasman eräiden lipoidiaineosien vaikutuksesta maitorasvan muodostukseen. Referat: Über den Einfluss einiger Lipoidbestandteile im Blutplasma der Kuh auf die Milchfetterzeugung. Acta Agralia Fennica, 57.2.

(2) - - 1950. A statistical study of the effect of excessive feeding of calcium and phosphorus supplements on the blood calcium and phosphorus of dairy cows. J. Sci. Agr. Soc. Finland, 22 , p. $122-131$. 
SELOSTUS.

\section{ALUSTAVA TUTKIMUS LEHMÄN VEREN KIVENNÄISKOKOUMUKSEN JA MAIDON SEKÄ MAITORASVAN ANNIN VÄLISISTÄ SUHTEISTA.}

P. SAARINEN

Yliopiston kotieläintieteellinen laitos.

Viidestätoista karjasta kerätyn 217 veri- ja maitonäytteen nojalla suoritettiin alustava tilastollinen tutkimus vertaamalla veren kivennäiskokoonpanoa samanaikaisesti tuotetun maidon määrään ja rasvapitoisuuteen. Tutkimuksessa on erikseen tarkasteltu veren natriumin, kaliumin, kloridien, fosfaattien, $\mathrm{Na} / \mathrm{K}$ suhteen ja $\mathrm{Ca} / \mathrm{P}$-suhteen sekä kationien ylimäärän vaikutuksia.

Koetuloksia tilastollisesti tarkasteltaessa näyttää veren kationeilla, kaliumia lukuunottamatta, yleensä olevan positiviinen vaikutus ja anioneilla negatiivinen vaikutus maidon määrään ja rasvapitoisuuteen.

Jotkin tässä alustavassa tutkimuksessa havaituista suhteista voivat ilmentää veren kivennäiskokoonpanon välittömiä vaikutuksia. Toiset sen sijaan ovat mahdollisesti välillisiä ja pikemminkin ilmentävät hormoonitoiminnan vaihteluita. Veren kaliumpitoisuus ja veren $\mathrm{Na} / \mathrm{K}$-suhde esimerkiksi näyttävät ensi sijassa ilmentävän lisämunuaisten ja munuaisten toiminnan tehokkuutta runsaan maidontuotannon vaiheessa. 